\title{
Determination of Design Solution for a $6 \times 6$ ATV with an Electromechanical Transmission
}

\author{
Kirill Evseev ${ }^{1, *}$, Aleksey Dyakov ${ }^{1}$, Roman Goncharov ${ }^{1}$, and Konstantin Chutkov ${ }^{1}$ \\ ${ }^{1}$ Bauman Moscow State Technical University, 105005 2-nd Baumanskaya street, Moscow, Russia
}

\begin{abstract}
The article provides an overview and analysis of the current state of development of $6 \times 6$ ATVs and the scope of the developed ATV, as well as technical characteristics of $6 \times 6$ ATVs with a mechanical transmission. The choice and justification of design solutions for a $6 \times 6$ ATV with an electromechanical transmission are presented. Also, the selected structural and design solutions for the developed ATV are substantiated based on the selected electric drive scheme taking into account the traction calculation for the selected electric motor.
\end{abstract}

\section{Purpose of the developed ATV}

The developed ATV with an electromechanical transmission and a 6x6 wheel arrangement is designed to transport people and small-sized cargo in off-road conditions except for virgin snow with a snow depth of more than $250 \mathrm{~mm}$ and is characterized by the ability to overcome natural and artificial obstacles such as slopes, slopes, trenches [1].

The 6x6 ATV with an electromechanical transmission includes the following main components $[2,3]$ :

- traction electric motor;

- motor controller;

- traction batteries;

- transfer box;

- final drive and differential;

- suspension system;

- steering system;

- brake system;

- electrical equipment [4];

- frame;

- cargo bed.

The logical continuation of the development of the branch of utilitarian ATVs is an ATV with a 6x6 wheel arrangement. Currently, in the model range of JSC Russian Mechanics an intermediate version is presented - an ATV with a $6 \times 4$ wheel arrangement. Based on the experience of operating an ATV with a $6 \times 4$ wheel arrangement it can be noted that the crosscountry ability and maneuverability are less in comparison with $4 \times 4$. This is because the third

\footnotetext{
* Corresponding author: kb_evseev@bmstu.ru
} 
axle is not driven. As part of the project a family of final drives was developed which includes the middle drive axle for a three-axle ATV. Thus, the issue of providing all-wheel drive is solved. Currently, there are $6 \times 6$ ATVs on the market, but their number is small and there is not one among them with an electromechanical transmission. The additional drive axle expands the utility vehicle's range of applications allowing it to carry more load and tackle more challenging terrain obstacles.

A distinctive feature of the vehicle under development is the rejection of the internal combustion engine which is the main source of noise in the ATV. In this regard a significantly lower noise level is predicted on the developed ATV. The use of ATVs with an electromechanical transmission and a reduced noise level makes it possible to expand the possibilities of carrying out special operations by special-purpose units of the Ministry of Internal Affairs in rough terrain. These vehicles can be used for reconnaissance and covert surveillance, patrolling and combat security, destruction of enemy manpower and combat equipment, target designation; conducting raids in areas where the enemy is deployed, conducting electronic warfare, adjusting artillery fire, evacuating the wounded, blocking difficult areas.

\section{Review and analysis of $6 \times 6$ ATVs}

The requirements for the characteristics of the developed ATV were formulated based on an analysis of the technical level of $6 x 6$ ATVs on the market since ATVs with a 6x6 wheel arrangement and an electromechanical transmission the design of which is the work of [5] are absent on the market; 6x6 ATVs with a mechanical transmission were chosen as analogues. Technical characteristics of 6x6 ATVs are presented in Table 1.

As a result of the analysis of the characteristics of ATVs of analogues the requirements for the developed ATV 6x6 with an electromechanical transmission were formed.

Table 1. Technical characteristics of $6 \times 6$ ATVs with mechanical transmission.

\begin{tabular}{|c|c|c|c|c|c|}
\hline Model & $\begin{array}{c}\text { Can-am } \\
\text { Outlander 6x6 } \\
\text { XT }\end{array}$ & $\begin{array}{l}\text { Polaris } \\
\text { Big } \\
\text { Boss } \\
8006 \times 6 \\
\end{array}$ & $\begin{array}{c}\text { Polaris } \\
\text { Ranger } \\
6 \times 6\end{array}$ & RM650-2 6x4 & $\begin{array}{c}\text { Developed ATV } \\
6 \times 6\end{array}$ \\
\hline $\begin{array}{c}\text { Dry weight, } \\
\text { kg }\end{array}$ & 517 & 489 & 704 & $\sim 510$ & 825 \\
\hline Payload, kg & $\begin{array}{c}363 \text { (bulk+ } \\
\text { baggage hold) }\end{array}$ & 507 & 907.2 & $\begin{array}{c}120 \text { (bulk+ } \\
\text { baggage hold) }\end{array}$ & 275 \\
\hline $\begin{array}{c}\text { Drawbar } \\
\text { trailer } \\
\text { weight, } \mathrm{kg}\end{array}$ & 780 & 680 & 907.2 & 450 & \\
\hline $\begin{array}{l}\text { Dimensions, } \\
\mathrm{mm}\end{array}$ & $3120 \times 1240 \times 1260$ & $\begin{array}{c}2950 \mathrm{x} \\
1245 \mathrm{x} \\
1245 \\
\end{array}$ & $\begin{array}{c}3480 \mathrm{x} \\
1520 \mathrm{x} \\
1930 \\
\end{array}$ & $3300 \times 1340 \times 1390$ & $3400 \times 1400 \times 1400$ \\
\hline $\begin{array}{c}\text { Engine } \\
\text { cubic } \\
\text { capacity, } \\
\mathrm{cm}^{3}\end{array}$ & 976 & 567 & 760 & 622 & \\
\hline $\begin{array}{c}\text { Engine } \\
\text { power, kW }\end{array}$ & 60 & 32.3 & 40 & 31 & 42 \\
\hline $\begin{array}{c}\text { Number of } \\
\text { seats }\end{array}$ & 1 & 1 & 3 & 2 & \\
\hline
\end{tabular}




\begin{tabular}{|c|c|c|c|c|c|}
\hline Model & $\begin{array}{c}\text { Can-am } \\
\text { Outlander 6x6 } \\
\text { XT }\end{array}$ & $\begin{array}{c}\text { Polaris } \\
\text { Big } \\
\text { Boss } \\
\mathbf{8 0 0 6 x 6}\end{array}$ & $\begin{array}{c}\text { Polaris } \\
\text { Ranger } \\
\mathbf{6 x 6}\end{array}$ & RM650-2 6x4 & $\begin{array}{c}\text { Developed ATV } \\
\mathbf{6 x 6}\end{array}$ \\
\hline Driveline & $\begin{array}{c}\text { Variator 2/4WD, } \\
\text { front differential } \\
\text { lock }\end{array}$ & $\begin{array}{c}\text { power- } \\
\text { operated } \\
\text { 2/6WD }\end{array}$ & $\begin{array}{c}\text { power- } \\
\text { operated } \\
\text { 2/6WD }\end{array}$ & $\begin{array}{c}\text { Variator 2/4WD, } \\
\text { front differential } \\
\text { lock }\end{array}$ & Electromechanical \\
\hline $\begin{array}{c}\text { Wheel } \\
\text { diameter, } \\
\text { mm }\end{array}$ & 660 & 660 & 489 & 660 & \\
\hline $\begin{array}{c}\text { Fuel tank } \\
\text { volume, } 1\end{array}$ & 20.5 & 25.5 & 34.1 & 24 & $\begin{array}{c}\text { Driving range } 100 \\
\mathrm{~km} \text { at a speed of } \\
60 \mathrm{~km} / \mathrm{h}\end{array}$ \\
\hline $\begin{array}{c}\text { Maximum } \\
\text { speed, kph }\end{array}$ & & & & 75 & 70 \\
\hline
\end{tabular}

\section{General design solutions}

The scheme "Electric motor instead of internal combustion engine" was chosen. The choice of such a scheme is due to high rates of unification with mechanical ATVs of the family of JSC "Russian Mechanics" and high rates of energy efficiency.

Based on the selected traction electric drive scheme the general design solutions of the developed ATV was determined shown in Figure 1.

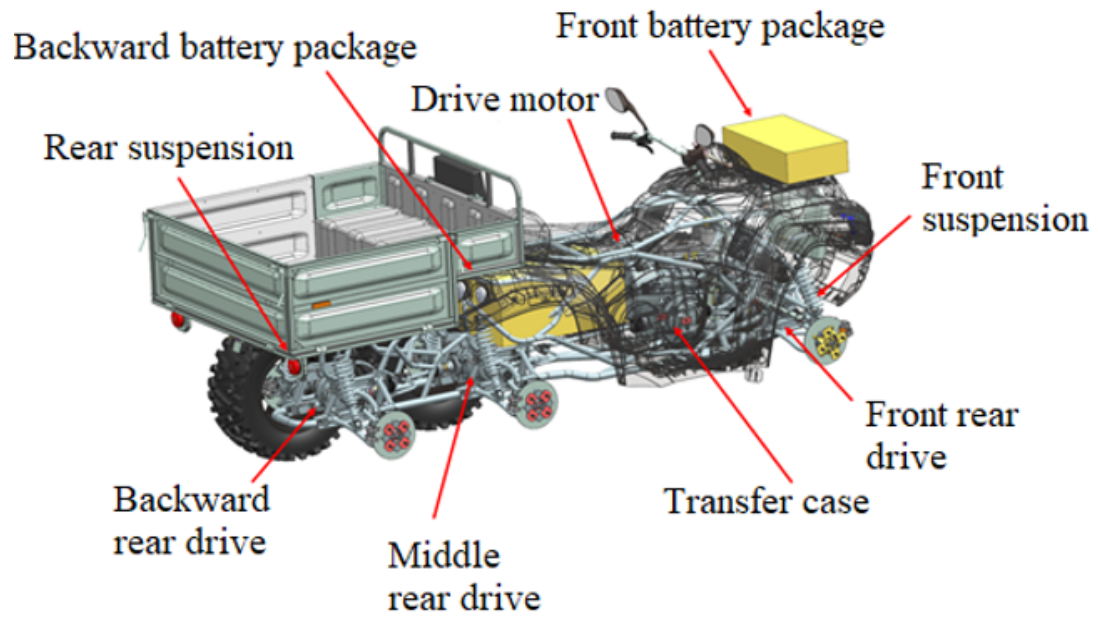

Fig. 1. General design solutions of the developed 6x6 ATV with electromechanical transmission.

In the central part of the vehicle there is an electric motor assembled with a transfer case. The motor controller is located above the transfer case. The entire battery capacity is divided into two blocks: front and rear. A cargo platform is provided for the transportation of a large amount of cargo.

\section{Traction calculation}

The set of the traction electric drive, consisting of a traction motor, a power converter, and an energy storage device, was selected based on meeting the requirements of the dynamic characteristics of the developed ATV as well as ensuring the specified cruising range. 
Based on a certain minimum engine power that ensures the movement of an ATV (18 $\mathrm{kW}$ ) with full weight at maximum speed on an asphalt road traction motors were selected for calculating traction dynamics and comparing the results. The following models of electric motors were considered: Lihao 260J, Emrax 207, Emrax 228. The main characteristics of the motors are given in Table 2.

Table 2. Characteristics of drive motors.

\begin{tabular}{|c|c|c|c|}
\hline & Lihao 260J & Emrax 207 & Emrax 228 \\
\hline Indicated power, kW & 25 & 21 & 42 \\
\hline Momentary output, kW & 50 & 40,7 & 100 \\
\hline Full-load torque, Nm & 80 & 58,9 & 125 \\
\hline Short duration rotative moment, Nm & 180 & 80 & 240 \\
\hline Maximum rotations per minute, rpm & 6000 & 6000 & 5000 \\
\hline $\begin{array}{c}\text { Nominal voltage, V } \\
\text { Weight, kg }\end{array}$ & 380 & 115 & 130 \\
\hline - diameter \\
- length
\end{tabular}

For each of the DM (drive motor) options under consideration the curb weight of the ATV was determined by subtracting from the curb weight of the base model RM650-2 [6-13] the masses of units that are absent in electric versions (internal combustion engine and its systems, variator, fuel tank, etc.), and adding masses of traction electric drive units (drive motor, batteries, etc.). The calculation results are shown in Table 3.

For each of the DM variants thrust calculations were carried out according to the results of which the product mobility indicators were determined.

Within the framework of the thrust-dynamic calculation the dynamic factor of the product was determined.

Table 3. Characteristics of drive motors.

\begin{tabular}{|c|c|c|c|c|}
\hline & $\begin{array}{c}\text { RM650-2 } \\
\mathbf{6 x 4}\end{array}$ & $\begin{array}{c}\text { Developed with } \\
\text { EM Lihao 260J }\end{array}$ & $\begin{array}{c}\text { Developed with } \\
\text { EM Emrax 207 }\end{array}$ & $\begin{array}{c}\text { Developed } \\
\text { with EM 228 }\end{array}$ \\
\hline Curb weight, kg & 578 & 676 & 630 & 633 \\
\hline $\begin{array}{c}\text { ICE weight with exhaust } \\
\text { and intake systems + } \\
\text { variator + transfer case, kg }\end{array}$ & 84.5 & - & - & - \\
\hline Drive motor weight, kg & - & 40 & 9,4 & 12,3 \\
\hline Transfer case weight, kg & - & 25 & 25 & 25 \\
\hline Fuel weight, kg & 20 & - & - & - \\
\hline
\end{tabular}




\begin{tabular}{|c|c|c|c|c|}
\hline & $\begin{array}{c}\text { RM650-2 } \\
\mathbf{6 x 4}\end{array}$ & $\begin{array}{c}\text { Developed with } \\
\text { EM Lihao 260J }\end{array}$ & $\begin{array}{c}\text { Developed with } \\
\text { EM Emrax 207 }\end{array}$ & $\begin{array}{c}\text { Developed } \\
\text { with EM 228 }\end{array}$ \\
\hline Battery weight, $\mathrm{kg}$ & 5.8 & 100 & 100 & 100 \\
\hline Transmitter weight, $\mathrm{kg}$ & - & 21 & 5,2 & 10,4 \\
\hline Mass of main gears, $\mathrm{kg}$ & 24 & 35,4 & 35,4 & 35,4 \\
\hline 3rd axle wheel drive, $\mathrm{kg}$ & - & 11 & 11 & 11 \\
\hline
\end{tabular}

The gear ratios of the transmission units were selected during traction calculations based on the provision of the maximum speed in the highest gear and the dynamic factor that ensures the overcoming of the maximum wheel adhesion to the lifting surface. The resulting gear ratios of the transmission units are presented in Table 4.

Table 4. Gear ratios of transmission units.

\begin{tabular}{|c|c|c|c|c|}
\hline $\begin{array}{c}\text { Transmission } \\
\text { unit }\end{array}$ & $\begin{array}{c}\text { Ratio of number } \\
\text { of teeth }\end{array}$ & $\begin{array}{c}\text { Transmission } \\
\text { unit }\end{array}$ & $\begin{array}{c}\text { Ratio of number } \\
\text { of teeth }\end{array}$ & $\begin{array}{c}\text { Transmission } \\
\text { unit }\end{array}$ \\
\hline $\begin{array}{c}\text { Transfer case } \\
\text { - high gear } \\
\text { - creeper gear }\end{array}$ & $\begin{array}{c}\mathrm{U}_{\mathrm{TC} 1}=2,1 \\
\mathrm{U}_{\mathrm{TC} 2}=5,04\end{array}$ & $\begin{array}{l}\text { Transfer case } \\
\text { - high gear } \\
\text { - creeper gear }\end{array}$ & $\begin{array}{c}\mathrm{U}_{\mathrm{TC} 1}=2,1 \\
\mathrm{U}_{\mathrm{TC} 2}=5,04\end{array}$ & $\begin{array}{l}\text { Transfer case } \\
\text { - high gear } \\
\text { - creeper gear }\end{array}$ \\
\hline Final drive & 3,7 & Final drive & 3,7 & Final drive \\
\hline
\end{tabular}

The results of calculating the dynamic factor are shown in Figures 2, 3, 4.

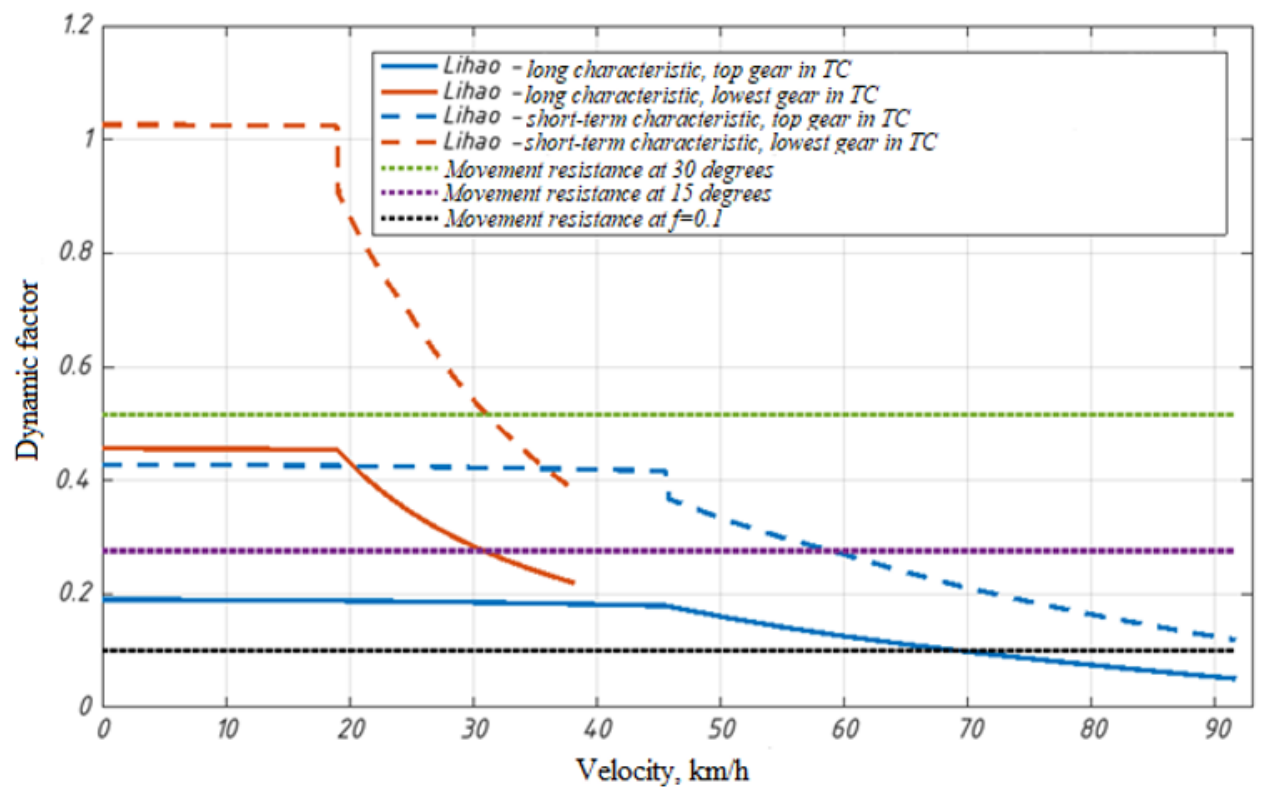

Fig. 2. Dynamic factor of an ATV with drive motor Lihao 260J. 


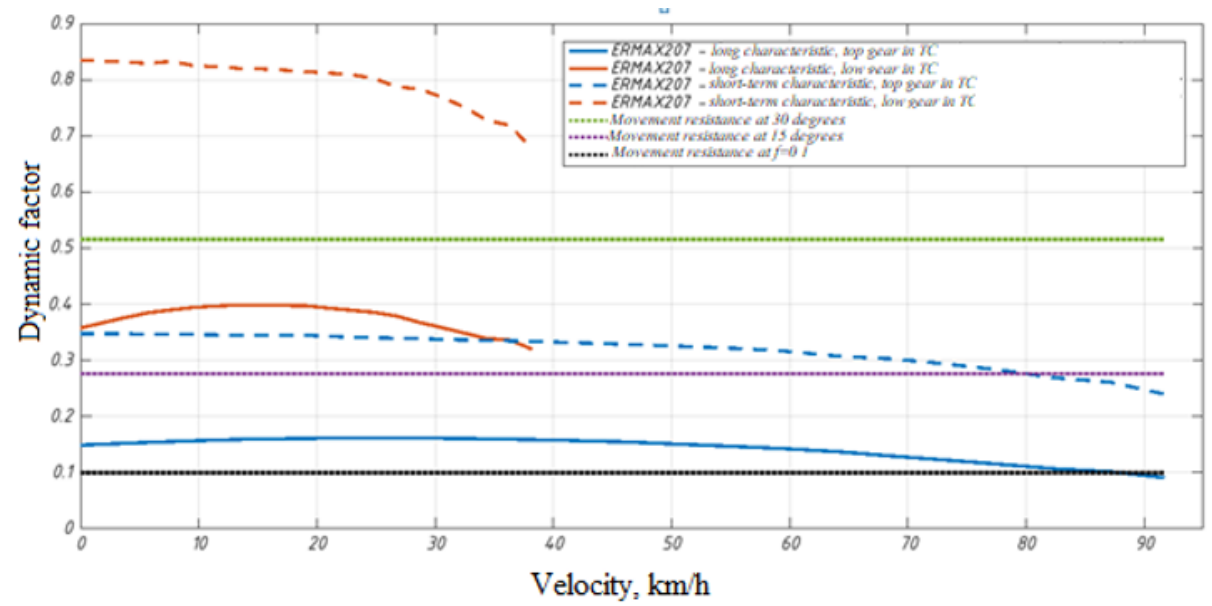

Fig. 3. Dynamic factor of the ATV with DM Emrax 207.

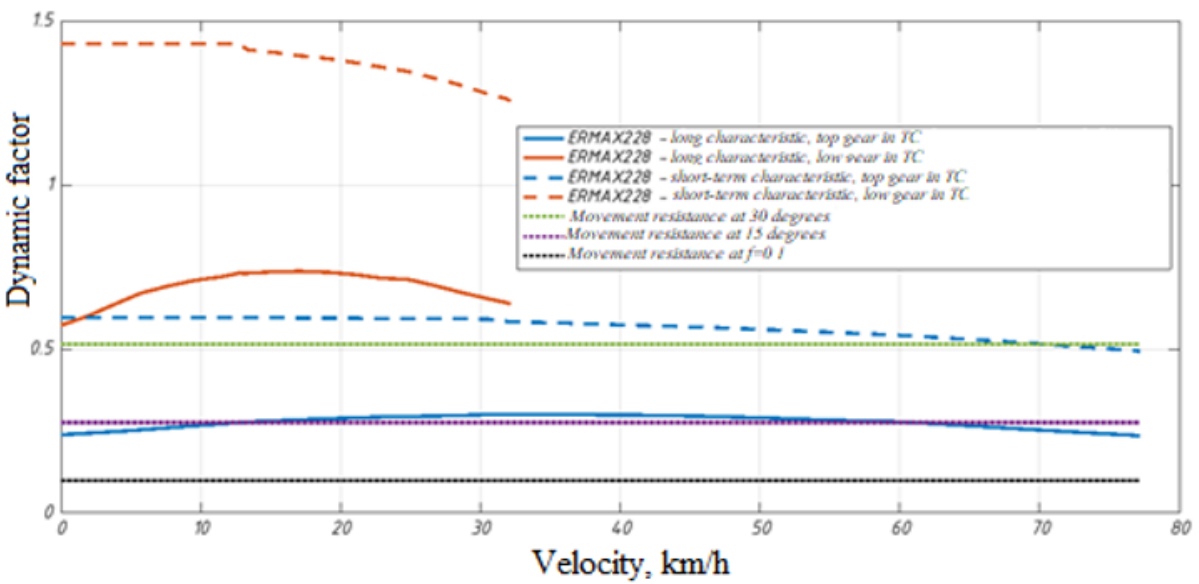

Fig. 4. Dynamic factor of the ATV with DM Emrax 228

Traction and dynamic calculations show that the ATV equipped with the Emrax 208 DM is significantly inferior to the other models under consideration in terms of the maximum dynamic factor and therefore in terms of acceleration time to maximum speed and, if possible, overcoming hills. An ATV equipped with a Lihao 260J traction motor with a full weight is not capable of climbing 30 degrees when operating on a long-term characteristic and cannot move at a speed higher than $70 \mathrm{kph}$ with a movement resistance of 0,1 . Also, the Lihao 260J DM is significantly inferior in weight to the Emrax 228 DM.

A review of analogs and a comparative analysis show that the Emrax 228 traction motor is the most suitable for use in the traction electric drive of an ATV.

Analyzing the graph of changes in the dynamic factor the following conclusions can be made:

1) the maximum speed of the ATV on an asphalt-concrete road (rolling resistance coefficient $\mathrm{f}=0,018$ ) is $80 \mathrm{kph}$ (it is possible to move at a speed of $90 \mathrm{kph}$ with a short-term operation of the traction motor at a higher voltage);

2) the maximum speed of the ATV on a dirt road in mud, sand or virgin snow ( $\mathrm{f}=$ $0,2 \ldots 0,4)$ - not less than $30 \mathrm{kph}$;

3) the maximum angle of ascent of the ATV of full weight on asphalt concrete pavement is not less than $35^{\circ}$. 


\section{Conclusion}

For this 6x6 ATV under development with an electromechanical transmission there are many design solutions determined by the selected electric drive scheme. Based on the purpose and scope of the developed product and the analysis of the advantages and disadvantages of various electric drive schemes the "Electric motor instead of the internal combustion engine" scheme was chosen based on which the general design solutions of the developed ATV was determined. As a result of the traction calculation, it was revealed that the Emrax 228 traction motor is the most suitable for use in the traction electric drive of an ATV.

\section{References}

1. V.V. Larin, Theory of motion of all-wheel drive wheeled machines (Publishing house of MSTU im. N.E.Bauman, 2010)

2. D.N. Reshetov, Machine parts: Textbook for students of engineering universities (4th ed., Rev. and add, Mechanical Engineering, 1989)

3. M.M. Zhileikin, G.O. Kotiev, Modeling of vehicle systems (Publishing house of MSTU im. N.E. Bauman, 2017)

4. D.A. Sosnin, Electrical, electronic and autotronic equipment for cars, (SOLON-PRESS, 2010)

5. A.I. Grishkevich, Design of car transmissions, (Mechanical Engineering, 1984)

6. V.V. Pozdeev, A.S. Diakov, Research and testing complex for analysis of vehicle suspension units, Procedia Engineering, v. 129, pp. 465-470 (2015)

7. G.O. Kotiev, B.V. Padalkin, A.B. Kartashov, A.S. Dyakov, Designs and development of Russian scientific schools in the field of cross-country ground vehicles building, ARPN Journal of Engineering and Applied Sciences, v. 1(4), pp. 1064-1071 (2017)

8. G.O. Kotiev, A.S Diakov, Advanced development and testing of off-road vehicle, DEStech Transactions on COMPUTER SCIENCE and ENGINEERING. 2nd International Conference on Computer, Mechatronics and Electronic Engineering (CMEE 2017), pp. 464-467 (2017)

9. A.S. Diakov, G.O. Kotiev, Establishment of production of special wheel and track technology for extreme natural-climate conditions of the Arctic, MATEC Web of Conferences, v. 224, (2018)

10. A.S. Diakov, V.V. Novikov, A.V. Pozdeev, The main directions of the development of snowmobiles in the Russian Federation, MATEC Web of Conferences, v. 224, (2018)

11. D.A. Chumakov, K.V. Chernyshov, V.V. Novikov, A.S. Diakov, A.S. Suchenina Mathematical model of motor vehicle air suspension with a combined damping system, IOP Conf. Series: Journal of Physics: Conf. Series, v 1177, (2019)

12. V.E. Klubnichkin, A.S. Dyakov, E.E. Klubnichkin, A.Yu. Zakharov, U.Sh. Vakhidov, A.S. Suchenina, I.V. Basmanov, Experimental evaluation of speed and brake properties of domestic and foreign made utility terrain vehicles, IOP Conf. Series: Journal of Physics: Conf. Series, v. 1177, (2019)

13. V.E. Klubnichkin, A.S. Dyakov, E.E. Klubnichkin, A.Yu. Zakharov, U. Sh. Vakhidov, A.S. Suchenina, I.V. Basmanov, Experimental evaluation of stability and controllability of domestic and foreign made utility terrain vehicles, IOP Conf. Series: Journal of Physics: Conf. Series, v. 1177, (2019) 